\title{
Old Books and E-Books
}

\section{Citation}

Darnton, Robert. 2007. Old books and e-books. European Review 15(2): 165-170.

\section{Published Version}

http://dx.doi.org/10.1017/S106279870700018X

\section{Permanent link}

http://nrs.harvard.edu/urn-3:HUL.InstRepos:3403051

\section{Terms of Use}

This article was downloaded from Harvard University's DASH repository, and is made available under the terms and conditions applicable to Other Posted Material, as set forth at http:// nrs.harvard.edu/urn-3:HUL.InstRepos:dash.current.terms-of-use\#LAA

\section{Share Your Story}

The Harvard community has made this article openly available.

Please share how this access benefits you. Submit a story.

\section{Accessibility}




\title{
Old Books and E-Books
}

\author{
R OBERT DAR N T ON
}

Department of History, Princeton University, Princeton NJ08544, USA.

E-mail: darnton@princeton.edu

The crisis in academic publishing has reached a point where young scholars in many fields of the humanities may no longer be able to communicate their research in the time-honoured manner - that is, in the form of a traditional codex printed by a university press. Sooner or later, most monographs will probably have to be published on the Internet. What form will they take? A tentative answer to that question is provided by a sketch for an electronic book about publishing and the book trade in 18th-century France.

Anyone who has admired a copy of Gutenberg's Bible might be tempted to argue that everything in the history of printing has been downhill since Gutenberg. The first important book to be printed from movable type in Europe is also the most perfect. Even its ink cannot be matched today. Yet bibliographers have demonstrated that the Bible was designed with the intention of cutting costs. By increasing the number of lines on a page - at first 40, then 41 , finally 42 - and by other devices, such as running the books of the Bible together instead of starting each of them on a new page, Gutenberg saved a great deal on the most expensive items of the production process: paper and vellum. The result leaps to the eye if you compare his layout with that of the 'Giant Bible of Mainz', a manuscript work completed between 1452 and 1453, which is profligate in its use of space. Gutenberg's Bible was a down-market product, appropriate for collective use in austere monasteries rather than for prelates and princes. Gutenberg set in motion the process that ultimately brought books into the hands of common people. He began the democratization of print culture.

That story, great as it is, does not necessarily lead to a happy ending. The publishing industry is now going through a crisis. I don't want to join the prophets of doom who have announced 'the death of the book,' because the book has been declared dead so often that it must be very much alive. Book sales in the United States have increased by $36 \%$ since 1997 . They increased by $4.6 \%$ in 2005 and brought in $\$ 23.4$ billion. The number of titles published worldwide each year is now greater than ever - more than a million, or a rate of publication that comes 
to one book every 30 seconds. Jeremiads about the death of the book remind me of my favorite graffito in the men's room of the university library in Princeton:

'God is dead' - (signed) Nietzsche; 'Nietzsche is dead' - (signed) God

No, the book is not dead, but university presses are dying. Faced with bankruptcy a few years ago, the Presses Universitaires de France closed its famous bookshop in the Place de la Sorbonne. A notice appeared in the shop window explaining that academic publishing had become economically unfeasible and recommended an article on the subject that I had recently published in Le Débat. Some polemics followed, which raised enough noise to be called 'the Darnton Affair.' I was flattered to be the subject of an affair in Paris, but I thought I had been misunderstood. So I would like to explain.

The cost of periodicals has skyrocketed. (The example librarians most love to cite is Brain Research, which now costs $\$ 21,269$ a year, but subscriptions to many journals in the life sciences come to more than $\$ 2,000$.) The increased expense has produced havoc in the acquisitions budgets of research libraries, which have responded by cutting back drastically in their purchase of monographs. And the drop in the orders for monographs has forced university presses to phase out whole areas of scholarship, especially dissertations on esoteric subjects. You know the cruel catchword of American academic life: 'Publish or perish.' I fear that young scholars are perishing everywhere - and that many university presses are doomed, too.

Although I am simplifying a complex situation, I think it fair to say that while the commercial book has adjusted to 21 st century conditions, the scholarly book is an endangered species. My own modest attempt to cope with the danger is a project sponsored since 1999 by the American Historical Association: Gutenberg-e. Thanks to a generous grant from the Andrew W. Mellon Foundation, the AHA conducts an annual competition for the best dissertations. The winners receive a prize of $\$ 20,000$, which they use to transform their doctoral theses into electronic books. Instead of merely rewriting their text, they redesign it in a fundamental way so that, with the help of computer scientists and specialized editors, they can incorporate all sorts of supplementary material: digitized manuscripts, images, recordings, films, and hyperlinks to other works. Eighteen Gutenberg-e books are now available online and the number will grow to 36 by the end of 2007. They have received excellent reviews, sold well, and have helped their authors to advance in their careers, despite some initial grumbling by older scholars who claimed that e-books can't be real books. The experiment has proved to be such a success that the publisher, Columbia University Press, now plans to continue Gutenberg-e as a self-supporting operation.

I agree that older scholars should volunteer as guinea pigs instead of performing experiments with the young. So I am now attempting to write an e-book of my 
own. It is a daunting experience, and it may not work; but I thought I might offer a brief, preliminary report as a way to illustrate my general thesis - namely, that e-books are not inimical to old books; on the contrary, the Internet can open up new ways of understanding how the printed word became one of the most powerful forces in our civilization.

Fifteen years ago, I set out to write a general study of the book trade in pre-revolutionary France. I had been through so much material - 50,000 letters in the papers of an important Swiss publisher, the Société typographique de Neuchâtel (STN), and thousands of other documents from the archives of the Book Trade Administration in Paris - that I could follow all the twists and turns of the book business in every corner of the kingdom. But that was the problem: I had too much information. I began drafting a chapter on the Loire Valley. First, Orléans, a great market for books: I had to tell the story of Couret de Villeneuve, the most eminent bookseller in town who cut quite a figure as a man of letters in the local academy but had difficulty honoring his bills of exchange. Then Blois: here the underground trade flourished, and I would have to provide a full portrait of Lair, a schoolmaster, who supplied his townsmen (and his students) with a spicy diet of pornography and philosophy. Next, Tours: not important in itself but rather as a base for the operations of the three Letourmy brothers, who peddled woodcuts and topical pamphlets throughout the area, undercutting the business of the established dealers. Then Amboise, then Saumur, then Anger, then Nantes, and detours to key distribution centers like Loudun and La Rochelle, each with its own constellation of fascinating characters. Fascinating, that is, to me: I realized that I would bore my readers to death, and so gave up.

Then along came the Internet. I saw the possibility of writing a new kind of book - in part a conventional narrative, which would be printed in the normal way; in part a collection of monographs and documents, which could be accessed through the Internet.

I now am drafting the first part, a survey of the book trade in provincial France from 1769 to 1789 . Because I am trying to write for the general educated reader, not merely for other college professors, I hope to hold the reader's interest by following a 'sales rep' (traveling salesman) of the STN, Jean-François Favarger, who climbed on a horse in Neuchâtel at the beginning of July 1778 and spent the next five months riding through southern and central France and inspecting every bookshop on his route. He sent regular reports to the home office, received fresh instructions in reply, and kept a diary with a detailed expense account: 10 sols for refurbishing his pistols in Marseille (the road to Beaucaire was infested with bandits), 26 livres for new breeches in La Rochelle (the old pair did not hold up against the friction in the saddle), and 8 louis for a new horse in Loudun (the old one kept collapsing on the muddy trails and finally had to be sold.) It was an extraordinary, un-sentimental journey. When Favarger arrived back in Neuchâtel 
in December, he knew more about the French book trade than any historian can ever hope to discover.

I intend to tap Favarger's street-level knowledge in writing a chapter about each of his main stops. To avoid boring the reader, I will move fast, in picaresque fashion. Anyone who wants further information can click down through successive layers in the electronic version of the book, which will contain a vast database linked to the original text.

For example, on July 7 Favarger crossed a pass through the Jura Mountains into France and spent the night in Pontarlier. On this leg of the journey, he concentrated on inspecting supply lines at the border, because the STN did a large business in illegal and pirated books, which had to be smuggled. Favarger negotiated over costs and risks with a half dozen smugglers in villages on both sides of the border. His reports and the correspondence of the smugglers are so rich that I decided to devote a chapter to the smuggling industry.

In it, I explain that two basic kinds of smuggling had evolved in the course of the 18th century. The first was called 'insurance.' Self-styled 'assureurs' guaranteed to get shipments of books from taverns on the Swiss side of the border to secret storehouses on the French side. They hired teams of 'porters', who received a stiff shot of schnapps in a Swiss inn - a favorite launching site was chez Jannet in the hamlet of Les Verrières - and then set off along tortuous mountain trails with the books on their backs. A backpack weighed 60 pounds $(30 \mathrm{~kg}$ ) under normal conditions, 50 pounds when the snow was deep. The men got 25 sols for a successful crossing. If caught, they could be branded with the letters GAL for 'galérien' and sent to row for nine years as a galley slave in Marseille. Their boss, the insurer, would then have to reimburse the STN for the full value of the merchandise. On January 23, 1784, Ignace Faivre, an insurer in Pontarlier, signed a contract with the STN that committed him to get its shipments across the border '.. at my peril and risk for 15 livres per hundredweight ... . In case of any unhappy event ['événement facheux'], I will reimburse the value of the merchandise within one year according to the prices on the bill of lading.'

But Faivre had to compete with rivals from the second type of smuggling, what I call the paralegal system. Using various techniques such as 'marrying' (larding leaves of prohibited books inside leaves of inoffensive ones), publishers hid dangerous works in normal shipments and sent them through the legal channels of the trade. The crates were sealed by French customs officers at the border, inspected by officials of the booksellers' guilds in certain 'villes d'entrée' such as Lyon, and then sent to their final destination, where they might be inspected yet again. Specialized forwarding agents ('commissionnaires') like Jacques Revol in Lyon often bribed the inspectors to do a superficial job. To be safe, however, they arranged for the wagon drivers to stop at an inn on the outskirts of the ville d'entrée - Aux Trois Flacons in the Croix Rousse suburb of Lyon, 
for example - where they would unpack the illegal books, replace them with legal works, bind the crate back up under a counterfeit seal, and send it on for inspection in the guild hall. Then they would forward the 'philosophical books' (a term in the trade for everything dangerous, from pornography to atheism) along another route, disguised as domestic merchandise.

This system worked well so long as the shipping agents and the wagon drivers coordinated their activities. But things were always going wrong. The STN often dealt with Jean-François Pion, a shipper in Pontarlier, who had a great stable of horses. He could yoke up five at a time to get loads over the Juras at the height of winter. His business suffered from one drawback, however: his stupidity. He once sent a crate to Nantes instead of to Rennes. He also forwarded a barrel of sauerkraut to the wrong address in Lyon, and it was devoured before the mistake could be corrected. So despite the excellence of Pion's horses, the STN constantly tried to find a substitute for him among the brainier peasants of the border towns - François Michaut and the Meuron brothers of Les Verrières and St. Sulpice, for example. But the small farmers could not supply enough horses during spring planting and 'the cheese season' in the fall. As a consequence of all these complications, the STN kept readjusting its smuggling operations. It was always playing off one smuggler against another, hoping to find cheaper rates and safer service, while calculating factors such as snow, horses, and the maturing rate of cheese.

I subscribe to the slogan: the devil is in the detail. But I do not want to smother my reader with stories about the colourful characters who got books across the Swiss-French border. I therefore plan to restrict my account of smuggling to a short chapter in the printed version of the book. The readers who desire more can $\log$ on to the electronic version, click down one level and take their pick of short monographs about Faivre, Revol, Pion, and a half-dozen other professional smugglers. If those short narratives excite more interest, the readers can click down to level three and read through selections from the smugglers' correspondence translated into English. Really serious readers can pursue the trail deeper down to level four, where I will provide transcriptions of entire dossiers in the original French. Transcriptions are invariably imperfect, however, owing to ambiguities in the manuscripts; so specialized scholars can click down to level five and study digitized versions of the originals.

This kind of book will require a new kind of reading, one that proceeds vertically as well as horizontally. It could also involve diagonal zigzagging, because I plan to intersperse each sector with maps, contemporary engravings of mountain passes, scenes of city streets, accounts of life in country inns, and hyperlinks to related themes in other dossiers. Each reader will find his or her own path through the material. Each will print out the parts that he or she finds most interesting. Each print-out can be trimmed and bound in a matter of minutes, 
thanks to technological advances in what is already a major industry: Print-on-Demand. The result should be an endless supply of custom-made paperbacks, every one different from all the others.

E-books of this kind will transform the relationship between writers and readers. Readers will become collaborators, or even adversaries, of the scholars who provide the components of each book. Although the material will conform to strict, academic standards, everyone can make of it what they want. There will be no fixed text and no limits, aside from built-in guarantees against falsifying the documents, to the empowerment of the readers.

Perhaps I am succumbing to utopianism. I know there are many objections to what I have proposed. I know it has flaws, and I shudder at the prospect of becoming entangled in the World Wide Web. But whether or not I succeed in this particular task, I hope I have said enough to substantiate the argument that old books and e-books are not enemies. They are allies. We need to build a strong alliance if we are to overcome the current crisis and to collaborate in the effort to expand Gutenberg's ever-lasting galaxy.

\section{About the Author}

Robert Darnton is Shelby Cullom Davis Professor of European History at Princeton University and was formerly Director in European Cultural Studies at Princeton. He was a Rhodes Scholar at Oxford 1960-64 and a Fellow at NIAS 1976-77. Among his books are Mesmerism and the End of the Enlightenment in France; The Business of Enlightenment: a Publishing History of the Encyclopédie; The Forbidden Best-sellers of Pre-Revolutionary France and George Washington's False Teeth: An Unconventional Guide to the Eighteenth Century. 